\title{
The Utilization of Colonial Government Buildings in Malang as the Learning Sources
}

\author{
$1^{\text {st }}$ Siti Ifroh Hana \\ Universitas Negeri Malang \\ Malang, Indonesia \\ Ifroh.Hana@gmail.com
}

\author{
$2^{\text {nd }}$ Wahyu Djoko Sulistyo \\ Universitas Negeri Malang \\ Malang, Indonesia \\ Wahyu.djoko.fis@um.ac.id
}

\begin{abstract}
Malang is a region that has a long history, ranging from Hinduism, Buddhism, Islam, Colonial to Republic. This can be seen from the legacies in the form of buildings scattered in Malang. One of them is the Colonial heritage, the site of the central government building which is a symbol of the greatness of the colonial government in Malang City. Among the sites of the building were the Regency Hall, the Assistant Resident's Office and the City Hall and Bunder Square. These sites can be used as a source of learning directly in historical learning to create realistic learning conditions
\end{abstract} sites

Keywords: Malang, history learning, central government building

\section{INTRODUCTION}

Along with the development of the era there is a shift regarding the paradigm in education. Initially the position of the teacher was recognized as the only source of information, in its development the teacher has the same position as other sources of information. The source of information provides learning experiences to students specifically and independently. In addition, information sources can also be obtained from many media, from the internet, books, to sites directly.

Shifting the direction of the new paradigm in education obtained several assumptions that developed in the concepts and practical education including according to [1] namely: (1) educators will have difficulty transferring teaching materials without regard to the characteristics of students; (2) students become the main focus in education; (3) cognitive teaching materials that are developed according to the development of science and community growth; (4) learning needs become the focus and source of curriculum program determination along with learning that students follow; (5) learning experiences that contain knowledge and skills will be more appropriate when presented in realistic conditions; and (6) the assessment needs to be done in a real and comprehensive manner. Through these assumptions, it can be concluded that the learning experience will be more appropriate if it is presented in real conditions.

One of the lessons that requires a real and realistic learning experience to achieve more appropriate learning goals is history. In his book Teaching of History states that history is often referred to as "queen" or "mother" of social sciences [2]. This is because history was born and developed long before other social sciences, besides that history is the basis of all scientific disciplines included in the categories of social sciences and humanities. Thus, the existence of history is a science that is indispensable for full human education. Learning history should be able to form a rational awareness of the future by understanding the value of the past. For this reason, it is important to create a realistic and realistic learning experience to achieve more appropriate learning goals.

Behind the importance of historical learning, several studies of undergraduate history education in higher education actually suggest that the historical learning conditions that took place in schools actually received a less positive response from students [3]-[5]. The reasons expressed also range from interest, variety to innovation that is felt lacking in the application of historical learning. In fact, back with the previous statement that historical learning should be able to form rational awareness and understand the values of the past, build ideology, a sense of nationalism to shape national identity and character.

In creating learning that real and realistic learning experiences can be helped through historical heritage and memorial buildings that contain certain values in accordance with historical events that lie behind them. One of them is the sites of heritage buildings in the colonial era which were built for the benefit of the colonial government in the colonies. This is in accordance with the statement from Maryati in [6] which suggests that, a building or site is able to present to the next generation the experience of ancestors and their predecessors. In other words, students can be 
faced with a re-writing of the collective experience of a nation called history.

Learning by utilizing the site as a learning resource is also considered important to bring about the closeness of the reality of students. This is as expressed by Mulyana in [7], that good history learning can come from students' daily experiences. Emotional closeness with the environment is a valuable learning resource. Emotional closeness can be achieved through local sites around students. As according to [8], although the standard of achievement in historical learning has been established by the national curriculum but there is no harm in teaching teachers to develop learning by utilizing local historical sites.

Malang is a region that has a long historical background. The historical sites in Malang vary according to the period of dismantling Indonesia's national history [9]. Starting from the Hindu-Buddhist era, Islam, Colonial to the Republican era. The distribution of these sites has the potential to be used as a learning resource both directly and packaged as media. One of the building sites is the colonial government central building in Malang. These buildings also reflect the symbol of the greatness of colonial rule in Malang.

Therefore in this article the author prepares a learning idea by utilizing a local historical building site as a direct learning resource. In this case, the sites utilized are the central government building located in Malang, which includes the Regency Hall, Assistant Resident's Office and City Hall and bunder Square.

\section{METHOD}

This writing uses a qualitative approach where the researcher seeks to express a reality of learning activities in the form of descriptive data obtained from interviews, observations / observations and documentation related to site conditions, student activities, and teaching teacher activities [10], [11]. Whereas for the historical data written in this article which is about the history of Malang City government building sites sourced from the stages of historical writing, namely: (1) Heuristics: collection of sources;

(2) source criticism; (3) interpretation; verification and synthesis; and (4) historiography; writing [12]-[14].

\section{RESULTS AND DISCUSSION}

\section{(3) Use of the Site as a Direct Learning Source in the form of} Project Based Learning

Historical sites are a direct source of learning. In this case the historical site as a learning resource has the following functions: (1) increasing the productivity of learning by road; (2) providing the possibility of more group learning; (3) provide a more scientific basis for learning by designing more systematic learning programs and developing teaching materials based on research; (4) strengthen learning; (5) allows learning instantly; and (6) allows the presentation of broader learning, by presenting information that is able to penetrate geographical boundaries.

In utilizing historical sites, of course, using outdoor learning or outdoor learning. Outdoor learning is a way to improve the learning capacity of students. Learners can learn more deeply through the objects they face than if they study in a class that has limitations. Learning outside the classroom can also help apply the knowledge they have [15], [16]. In general outdoor learning can be divided into 3 types, namely: 1. Field studies, 2. Education explores the environment, 3 . Community school projects. In this case, the author explained the scheme of outdoor learning activities using a type of community project school or project based learning. The stage presentation will also be complemented by the utilization of the colonial government central building site in Malang with the project based learning type outdoor learning model. Project based learning is an innovative learning model or approach that emphasizes contextual learning through complex activities [17]. The focus of this learning lies in the concepts and principles of the material being studied, involving students in investigating problem solving and task activities and giving students the opportunity to work autonomously and construct their own knowledge.

There are four main characteristics in project-based learning, namely: content, conditions, activities and results. In general, the steps in the project based learning model for outdoor learning [16], [18], [19] is as follows:

\section{- Establish the project theme}

In determining the theme of the project it should meet the indicators: (1) contain general ideas; (2) important and interesting; (3) describe complex problems; (4) reflect the relationship of various ideas. In this case students are formed in collaborative groups to be able to solve problems together and discuss each other. An example in the project theme is: Get to know local history through colonial heritage sites in Malang City. In this big theme, it is further reduced by each group focused on one site in Malang City. These themes included the Regency Hall, Assistant Resident's Office, and Bunder Square. All three are symbols of the greatness of the colonial government. It is hoped that through these themes it can describe the government occupied by colonialism. In addition, more importantly, educators provide introductory material. Material presentation that will provide students with initial and basic understanding before they conduct exploration [4]. Introduce to the material used as a sources of learning 
activities is about the sites of government buildings that show poor as a colonial city.

\section{- Understanding students of colonial government buildings}

The Dutch Colonial Government adopted an indirect government system. As a consequence, in the system there are two bureaucracies, namely: the bureaucracy of European employees (Europeeschebestuur) and the bureaucracy of Bumiputra (Inlandschbestuur) or better known as pangrehpraja. In the Bumiputra bureaucratic structure the highest position is in the hands of the Regent. When compared to the chain of European employee bureaucracy, the position of the Regent is almost the same as an assistant resident or head of afdeeling [20]. In running his government the Regent lived in the Regency Hall while the Resident Assistant lived in the Malang Resident Assistant Office.

\section{B. Establish the Learning Context}

After the students are divided into groups, the rules of learning are conveyed. Autonomy of students must be prioritized and delivered time to students. The processing time does not have to be done in one learning session. However, it can be done outside of classroom learning. Students are required to be able to manage time effectively and efficiently, learn with full self-control and simulate work professionally. In this case the processing time for each group is two meetings. The two meetings were allocated for literacy studies and field studies as well as the preparation of reports obtained through these two activities. Students are required to display results in accordance with the theme obtained and the desired learning target.

\section{Plan Activities}

In achieving the targets in the project given students are directed to plan activities as follows:

- Reading: by reading literacy that is related to the theme obtained by each.

- Research: by observing the sites studied, namely the district pavilion, the resident assistant office and the bunder square.

- Internet access: to increase knowledge about the development of sites studied.

\section{Process Activities}

After the planning is done, students are asked to process activities as planned. In this activity process students can carry out activities such as sketching, painting analysis, counting and others.
- $\quad$ Conduct analysis of observations

The new city center is built with a large round garden. This garden with a beautiful fountain is located in the middle of a residential area. On the continent of Europe, there are a lot of garden models like this, because there are so many parks like this and there have been a stream called the Formal Axial Tradition in terms of building arrangement and urban arrangement. The existence of the fountain is very prominent, because the nature of the fountain gives a change of atmosphere. Water can give a change of atmosphere, bring a change in sound and spread a calming cold. Reflection of shadows produced by the surface of the water is also a special attraction for visitors to the park [21].

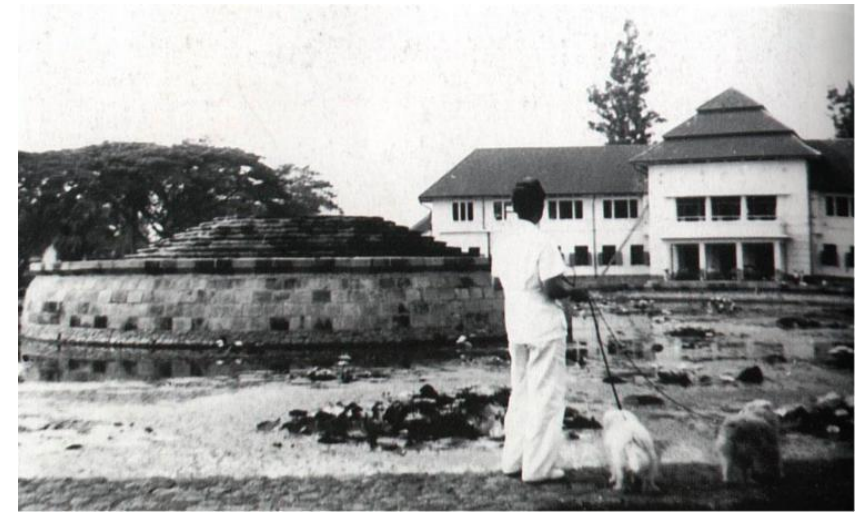

Figure 1. Bunder Square which has a background in the City Hall Building

There is a fairly basic difference between the fountain in Coenplein and the fountain in the park in the Netherlands. If the pond in Malang is empty without statues while almost every pond in Europe is decorated with statues as a point of attention. The function of this attractive statue is the identity of an area. Tugu, which currently stands in the middle of the Bunder Square, was only built in 1950, after the Dutch left Malang City. The inauguration of the monument was carried out by President Soekarno [21]. The coen plan is surrounded by many circular branches that lead to the surrounding residential area. This ring road system is the solution if there is traffic congestion around the city center. Because the ring road is an alternative road that provides an opportunity or alternative road that provides an opportunity or a way out for the flow of traffic that passes through the city center. So, this radial city structuring system does not bring difficulties to the flow of traffic. While the grid arrangement system (which resembles a symptom) is a flexible system because it can be developed in all directions. This system is applied to residential areas in the Gouverneur-Generaalbuurt area [21]. The existence of the bunder square as a center for the community to 
gather further emphasized the triumph of colonial rule with City Hall buildings around the park.

\section{E. Application of Activities to Complete the Project}

In this step, the settlement is carried out based on the sketch that has been made, testing the steps carried out and the results obtained. Then package in the form of the desired report. Furthermore, it is prepared to present the results of the project. Assessment is based on the rubric made by the teacher and agreed upon by the students.

- $\quad$ Students package reports according to the theme of each group

Regency Hall :The Regent is a traditional leadership position that has had a long history in Java. In Malang, the regent's position can be mapped with Akuwu or dukes. Before the reign of Governor General Deandels at the beginning of the 19th century, regent power was like a local king and was legitimized by the belief in the mystical power inherent in him. This form of legitimacy was maintained from the time of the Hindu State to the Islamic Mataram State. The model of the ruler who uses this legitimacy produces a bond between the ruler and the people in the form of a personal bond [20]. The Bupati as a traditional leader lives in the Regency Hall. Based on the Letter of Resolution October 31, 1820 No. 16, Hall of residence of Malang Regent was built in 1839 by Raden Panji Wielasmorokoesoemo and after was appointed as Regent of Malang and changed his name to Raden Tumenggung Notodiningrat. At that time Malang Regency was part of the residency region. Pasuruan based on Staandblad 1819 No. 16. Malang Regency Hall Building has been used as the residence of the first regent from 1839 until the 18th regent in 2002 [22], [23].

Assistant Resident Office : Position of Malang based on Staadblad 1819 No. 16 is the residency Pasuruan territory, then in Malang City an official resident is placed. In 1824 the assistant resident occupied the office of the Assistant Resident's office which is currently the Post Office. Because in 1928 Malang became the resident capital, then in 1936 the Bestuurkantor building was built, the Malang Resident office. The building was built by architect Ir. M.b. Tideman until now has not experienced significant changes. At present the resident assistant building is the Regional Treasury and Cash Office [24].

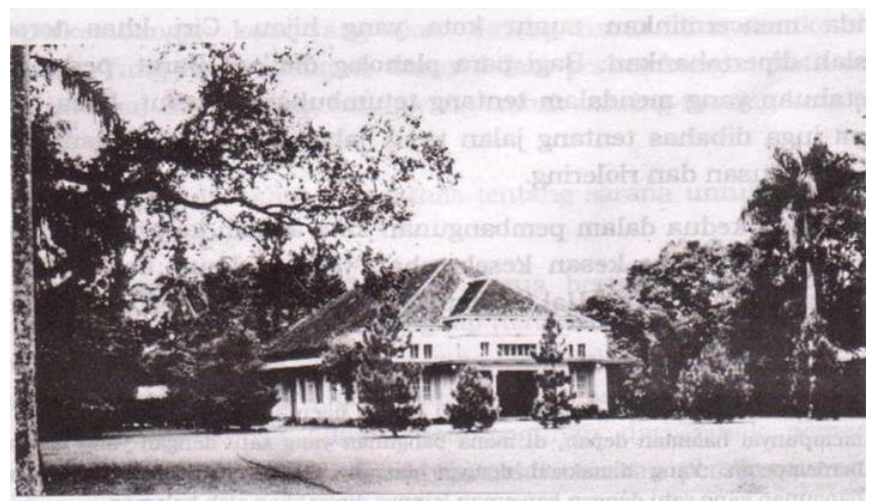

Figure 2. Malang Resident Assistant Office taken around 1910. Looks like the Pool in front of the building is gone and repairs to the building [25]

City Hall Building and Bunder Square: After 1900 in Malang and the cities of the Netherlands East Indies, many full-blooded Dutchmen arrived from Europe. This new generation wants to give the impression that the city is more Western in style. They want the city center to move from the square. After the city of Malang held the status of Gemeente in 1914 and the capital of the Residency of Pasuruan in 1927, the idea to move the center of government was carried out. The city also has a strategic meaning which is characterized by the existence of a base of defense and the position of the Dutch East Indies army. The function of the government that has been represented by the office of the assistant resident is confirmed by the presence of the Gemeentehuis (City Hall) building. The building was considered a symbol of the presence of the Colonial Government in the midst of the Bumiputra community, city unity, and the superiority of the city of Malang compared to other cities on the island of Java. The City Hall Building was inaugurated on January 15, 1930, giving two messages, namely: (1) the inauguration of the building also seemed to be marking the end of modern Malang city development; and (2) large buildings, namely the Gemeentehuis building being the flagship center of Gemeente Malang compared to other Gemeentegemeente. Furthermore, the city hall building can be completed on September 1, 1929 and can be used [20].

All matters relating to public services are held downstairs. Technical affairs are on the left wing while the book and cash order section is on the right wing. In addition, there are labor exchanges, tax and cash services. Left wing there is also a local health service room and population registration. The center or center of the city hall is the council building, the left wing is the Burgermester room and the secretary, while in wing kana the tone of the commission room and the werhouder room. The total area of this building is 
2,600 m2. The building's space is decorated with portraits of Bussemaker and medals honoring his services. Almost all elements of the city community give souvenirs at the inauguration of the city hall building. This city hall building also proves that the Board has succeeded in realizing what has become the city's needs so far [20].

It was explained earlier that the city hall building was built in the coenplein area or its long name was Jan Pieterzoen Coenplein. Coenplein is a large park that is large in shape and flanked by city hall buildings and HBS / AMS schools or commonly called the bunder square. Coenplein was built by the Dutch to become a city center as well as a new center of government. Since Malang became a municipality and began to be led by a mayor on July 1 , 1919 the presence of a new government building was absolutely necessary. The old square square which is the independent square is no longer considered the center of the city because it is seen as still smelling of Indisch by most Dutch people [21].

\section{CONCLUSION}

Local history sites can be used as a source of learning in a realistic and real way. The use of local historical sites can be done with outdoor learning activities with a constructivism approach. The model that can be developed in learning with the use of local historical sites is Project based learning with students being asked to form groups in achieving the given project. This model is carried out through several meetings with stages including (1) determining the theme of the project; (2) determine the learning context; (3) Planning activities; (4) process activities and (5) implement activities to complete the project.

\section{REFERENCES}

[1] I. Abdulhak and D. Darmawan, Teknologi Pendidikan. Bandung: PT Remaja Rosdakarya, 2017.

[2] S. K. Kochar, Teaching of History. Jakarta: PT Grasindo, 2008.

[3] J. Sayono, L. Ayundasari, W. D. Sulistyo, and R. Ridhoi, "Utilization of Syphon Metro Kepanjen as Outdoor Learning Site for History Students," in 1st International Conference on Social Knowledge Sciences and Education (ICSKSE 2018), 2019.

[4] W. D. Sulistyo, "Learning Activities from Learning Resources: Pemanfaatan dan Pemaknaan Situs Sejarah Kawasan Alun-Alun Merdeka Kota Malang," Jurnal Pendidikan Sejarah Indonesia, vol. 2, no. 1, pp. 4963, 2019.

[5] W. D. Sulistyo, "Study on Historical Sites: Pemanfaatan Situs Sejarah Masa Kolonial di Kota Batu sebagai sumber pembelajaran berbasis outdoor Learning," Indonesian Journal of Social Science Education (IJSSE), vol. 1, no. 2, Sep. 2019.

[6] P. P. E. Suardi, "Pemanfaatan Monumen Perjuangan Bangsal sebagai Sumber Belajar Sejarah Bagi Generasi Muda di Desa Dalung, Badung,” Jurnal Candra Sangkala, vol. 1, no. 1, 2013.

[7] N. L. Zahroh, "Pemanfaatan Situs Singosari dalam Mengembangkan Literasi Sejarah Peserta Didik," J-PIPS, vol. 1, no. 1, p. 159, 2014.
[8] I. Purnamasari, "Pengembangan Model Pembelajaran Sejarah Berbasis Situs Sejarah Lokal Di Sma Negeri Kabupaten Temanggung," Paramita: Historical Studies Journal, vol. 21, no. 2, 2011.

[9] Joko Sayono, L. Ayundasari, W. D. Sulistyo, and R. Ridho'i, Situs Sejarah Malang Raya Masa Islam dan Kolonial. Malang: Jurusan Sejarah FIS UM, 2019.

[10] H. R. Bernard and H. R. Bernard, Social research methods: Qualitative and quantitative approaches. Sage, 2013.

[11] J. W. Creswell and J. D. Creswell, Research design: Qualitative quantitative, and mixed methods approaches. Sage publications, 2017.

[12] D. Abdurahman and A. Safa, Metodologi penelitian sejarah. Ar-Ruzz Media, 2007

[13] A. Dudung, "Metodologi Penelitian Sejarah," Jakarta: Ar-Ruzz Media, 2007.

[14] M. Lange, Comparative-historical methods. Sage, 2012.

[15] H. Husamah, "Pembelajaran Luar Kelas (Outdoor Learning)," Research Report, 2013

[16] Y. Wibowo, "Bentuk-bentuk Pembelajaran Outdoor," Yogyakarta: Jurusan Pendidikan Biologi FMIPA UNY, 2010.

[17] S. Bell, "Project-based learning for the 21st century: Skills for the future," The Clearing House, vol. 83, no. 2, pp. 39-43, 2010.

[18] H. Bilton, Outdoor learning in the early years: Management and innovation. Routledge, 2010.

[19] J. E. Dyment, "Green school grounds as sites for outdoor learning: Barriers and opportunities," International Research in Geographical \& Environmental Education, vol. 14, no. 1, pp. 28-45, 2005.

[20] R. R. Hudiyanto and A. W. Wirayuda, Menciptakan masyarakat kota: Malang di bawah tiga penguasa 1914-1950. Penerbit Lilin, 2011.

[21] D. I. Widodo, Malang Tempo Doeloe. Surabaya: Dukut Publishing, 2015

[22] D. Cahyono and Syarifuddin, Malang, telusuri dengan hati. Inggil Documentary, 2007.

[23] M. D. Cahyono and Tim, Sejarah Daerah Batu, Rekonstruksi SosioBudaya Lintas Masa, 1st ed. Batu: Jejak Kata Kita, 2011.

[24] B. Suprapta, "Model Pemanfaatan Cagar Budaya untuk Kesejahteraan Masyarakat Studi Kasus Event Malang Kembali," Jurnal Sejarah dan Budaya, vol. 10, no. 1, pp. 11-30, 2016.

[25] Handinoto, "Perkembangan Kota Malang Pada Jaman Kolonial (19141940)," DIMENSI (Journal of Architecture and Built Environment), vol. 22, pp. 1-29, 1996. 